\title{
SOCKET SHIELD TECHNIQUE FOR DENTAL IMPLANTS IN THE ESTHETIC ZONE, CLINICAL AND RADIOGRAPHICAL EVALUATION
}

\author{
SANDy ANDraws HANA ${ }^{*}$ and OTHMAn ABUbaKir OMAR ${ }^{* *}$ \\ *Dept. of Maxillofacial Surgery \& Periodontics, College of Dentistry, University of Dohuk, \\ Kurdistan Region-Iraq \\ *** Dept. of Oral and Maxillofacial Surgery, College of Dentistry, Hawler Medical University, \\ Kurdistan Region-Iraq
}

(Received: November 26, 2019; Accepted for Publication: February 17, 2020)

\begin{abstract}
Background and objective: The socket shield technique where the buccal fragment of the root is left attached to the socket wall before the dental implant insertion. The purpose of retaining the buccal fragment is to aid in restoring the esthetic natural appearance around dental implant.

Aim: To assess the role of the retention of a buccal part of the root in preserving the pre-implant esthetic and functional condition.

Methods: Forty patients had been enrolled randomly. Twenty cases of socket shield technique as study group and twenty cases of conventional immediate implant as control group, and these two groups were followed up and evaluated for the implant survival, pink esthetic score for the soft tissue related to dental implant, and radiographically with PA and O.P.G in addition to CBCT that aid in finding any pathology or bone defect and the thickness of the buccal bone related to placed implant.

Results: One case failed out of twenty of each group. $95 \%$ success rate. With the clinical evaluation of pink esthetic score the socket shield technique showed a higher value that approximates the natural teeth 12.26, while in conventional technique there was decrease in the values of pink esthetic score 9.63. The results of the conventional immediate implant technique were unpredictable, and some of the cases after one year needed soft tissue graft to repair the esthetic defect that was not needed in socket shield technique.

Conclusion: The Socket shield technique could be a good choice and treatment modality for the esthetic zone. It gives the optimum esthetic results but still needs a very experienced surgeon to prevent the complications that are related to this technique.
\end{abstract}

KEYWORDS: Socket Shield, Bone Loss, Buccal Bone, Esthetic Zone, Pink Esthetic Score. https://doi.org/10.26682/sjuod.2020.23.1.8

\section{INTRODUCTION}

A fter tooth extraction, one of the most common complications is dimensional changes in alveolar ridges which is difficult to be avoided or reversed, so this shrinkage is an unfavorable physiological change for the restorative procedures (1). This bone loss that occurs after extraction mainly in the buccal plate occurs as a result of losing ligament and its related blood vessels, which regarded as important blood supply for the nourishment of buccal plate, especially in anterior maxillary teeth which commonly have a delicate and thin buccal plate (2). And as a result of buccal bone loss, the overlying soft tissue will be negatively affected because it will lose its support and will shrink as underlying bone resorbed (3). There are some steps during surgical procedures that thought to help in maintaining post-extraction socket by decreasing alveolar bone resorption, for example, atraumatic extraction, socket preservation technique and immediate implant placement (4). Using socket preservation procedures may control ridge resorption to some degree, but that procedure rarely results in complete preservation of the alveolar ridge frame. (5) Also, it is known that immediate implant doesn't act to prevent the buccal bone resorption, so some methods are needed to be used to decrease the effect of that resorption on dental implant like, availability of not less than $2 \mathrm{~mm}$ width of the buccal bone crest, placing implant palatally and adequate implant diameter 
in proportion to the width of the ridge. (6)

It is essential to take in consideration when restoring the area of extracted tooth or teeth either with fixed bridges or dental implant, not just the proper design and shade of crowns or bridges, but also to the soft tissue which includes the papilla and the gingiva keratinization and the harmony of appearance which is very important aesthetically. $(7,8)$

The socket-shield technique (SST) which is one of alveolar ridge preservation procedures similar in the principles to the root submerging technique, was first introduced by Hürzeler et al, he described this technique as with keeping a buccal fragment of the tooth that will be extracted, specifically the vestibular portion of the most coronal third of the root, aiming to prevent the buccal cortical bone from resorption $(4,9)$.

The known advantages of SST are; a minimally invasive technique, help in maintaining hard and soft-tissue contours, minimizes the need soft and hard tissue grafting procedures, shortens the overall treatment duration, the interdental papilla can be preserved by preparing interdental socket shield, and lastly it is a highly promising technique in terms of maintaining pink and white aesthetics and provides a solution for esthetically critical cases such as high lip line (10). There are also some disadvantages or complications with the SST are; Buccal/crestal bone loss, failure of osseointegration, shield exposure/failure, cementum formation on implant surfaces, Pocket formation, inflammation, and mucositis (11).

This study is done to compare the esthetic results between conventional immediate implant placements with the immediate implant placement by the socket shield technique, this evaluation was done with the aid of pink esthetic score.

\section{MATERIALS AND METHODS}

This study is conducted with the evaluation of success rate of the socket shield technique in both esthetic and functional aspects and assess the benefits and shortcoming of this technique, and trying to make an addition information to the data or the knowledge about this technique, as it needs many studies to increase the data about this procedure.

\section{Study Sample}

This study is a combined, retrospective comparative study. The sample for this study composed of 40 selected patients according to inclusions and exclusions criteria; these cases were selected from patients visiting the specialized center of dental implant at Rizgary teaching hospital. And these cases were divided into two groups the first group is 20 patients with a socket shield technique and the second group is 20 with a conventional immediate implant. The dental implants used in this study were (Euroteknika) System.

\section{Inclusion Criteria}

- The implanted teeth included from the $1 \mathrm{st}$ premolar of the right to the left sides in the esthetic zone of the maxilla.

- The selected cases should be medically healthy adult both males and females (ASA classification I-II.).

- Age $\geq 25$ years old, Non-smoker or mild cigarette smoker, a hopeless anterior tooth with mostly neighboring teeth on the mesial and distal.

Intact buccal periodontal tissues, and finally, the patients should have good oral hygiene.

\section{Materials}

Dental syringe, anesthesia cartridge (lidocaine hydrochloride $2 \%, 1.8 \mathrm{ml}$ ), needle, Dental implant surgical kit, Oral surgical kit (scalpel, blade, periosteal elevator, needle holder, scissor, cheek retractor, suturing materials), Dental mirror and periodontal probe, Surgical sucker, Dental implant engine with the handpiece, Turbine and special burs for preparing root shield, Upper anterior forceps, root forceps, elevators, and peristome, Impression materials. As shown in Figures (1) and 


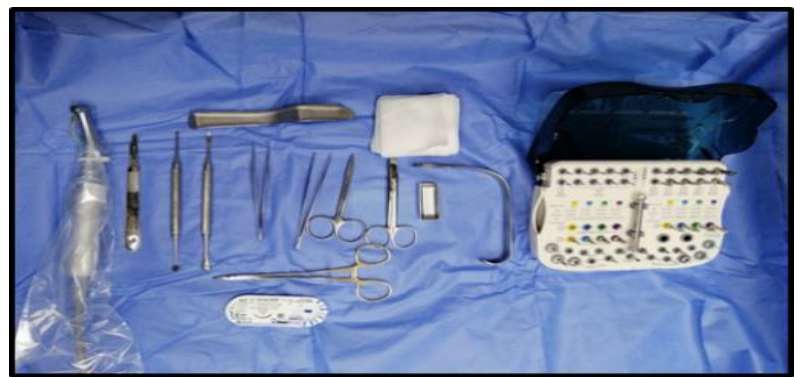

Figure 1: Showing the surgical kit with a dental implant kit.

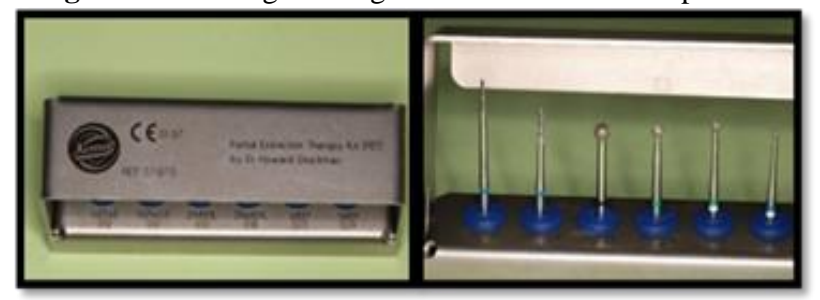

Fig. (2): Showing special burs used for SST procedures.

\section{Surgical Procedure}

- All the patients were asked to rinse their mouths with $12 \%$ chlorhexidine for not less than 30 seconds, followed by disinfection of the skin around the mouth with gauze swapped with povidone-iodine solution.

- After preparing the patients, the conventional immediate implant placement started by giving the required amount of anesthesia needed for the surgery by infiltration technique, then extraction of the tooth was done with minimum trauma to the periodontium then the type I or II sockets was prepared for the placement of the implant.

- While in socket shield technique the crowns of the involved teeth were removed using diamond bur to a level not more than $1 \mathrm{~mm}$ above the alveolar crest, to preserve dentogingival fibers intact which result in more esthetic appearance of soft tissue, then the remaining roots were split mesiodistally by special kind of burs so the roots were divided in to buccal and palatal part which is larger size and attached with the apex of the tooth, the palatal part was weakened and removed carefully leaving the smaller buccal piece which was about $2 \mathrm{~mm}$ thickness and reduced incisally with approximately the level of the crestal bone.

- when emphasized that the root shield wasn't mobile the tooth socket was prepared for implant placement, and distance was kept from the root shield (about 1-2 mm), then the fixture with appropriate length and diameter was inserted in the prepared site with insertion torque with average of $49 \mathrm{Ncm}$ after that abutment or gingival former were placed, so all SST cases were immediately loaded. What SST results in is implant attached to the bone in palatal, mesial, and distal directions while there is a free distance in the buccal border, so buccally there are cementum, dentin, periodontal ligament, and buccal bone lamella.

- After finishing surgical procedures patient was instructed to continue antibiotic treatment mostly with the amoxiclave tab. $1 \mathrm{~g}$ twice daily for five days in addition to oral hygiene instructions using $0.12 \%$ chlorhexidine mouth wash for two weeks and to be seen after three months for evaluation and replacement of the temporary crown with permanent one.

- Following up the patients of both SST group and CII group for evaluation was done by obtaining the results of the 38 dental implants in a total of 40 dental implants each group had one case failed, and the teeth had been extracted in study group were 8 central incisors, 6 lateral incisors, and 6 canines, While in the control group were 9 central incisors, 6 lateral incisors, and 5 canines. The gender of the patients was 24 male 16 female, the age ranged from 28 years to 65 years for both female and male with mean age of 51 years, and those cases were formed of 20 cases of SST as study group, and the 20 conventional immediate implanted cases as control group. (Figure 6)

- The dimensions of implants used in the study ranged from 3.5 to 5 with a mean of $4.1 \mathrm{~mm}$ diameter, and from 11 to 14 in length with an average of $12.3 \mathrm{~mm}$, no graft materials or 
membranes were used.

- Provisional rehabilitation was done with acrylic resin for immediate loading cases after one to 4 days of the surgical procedure according to facilities available and lab cooperation. The definitive restorations were porcelain-fused-to-metal cement-retained restorations that were fabricated 3 to 6 months after.

- Radiographic evaluation for SST cases was done with CBCT to evaluate any problem with the shield and if there is resorption or presence of any pathology related to it, that were obtained at each patient's latest follow-up visit.

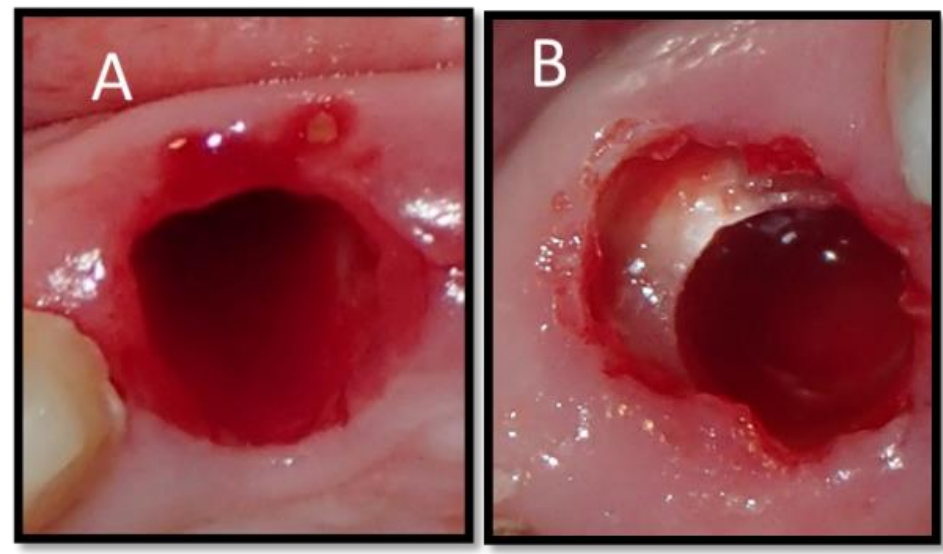

Fig. (3: A) show socket after the tooth removal with conventional technique, B) tooth extraction socket with SST.

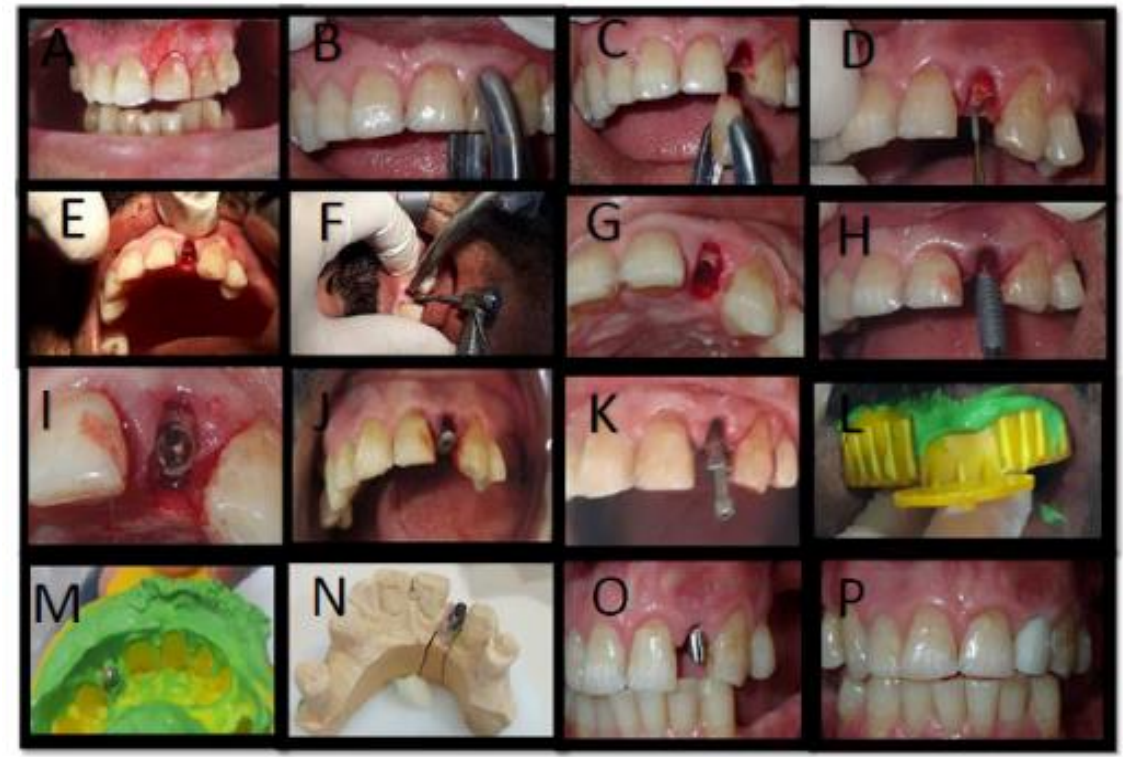

Fig. (4): Illustrated the steps from the beginning of the procedures till insertion of temporary crown of tooth 22 ; A, B and C: show horizontally fractured crown being removed, D: starting the mesio_distal sectioning with special kind of long bur, E and F: further preparation of the site by leaving the buccal fragment of the root, G: finished site of tooth 22 and ready to insert of implant in the prepared bed, H: implant insertion, I: show implant with the shield, J:gingival former, K: impression post, L and M:taking impression with open tray technique, $\mathrm{N}$ :lab work, $\mathrm{O}$ and $\mathrm{P}$ : insertion of temporary crown then to be replaced by permanent one after 2 to 3 months. 


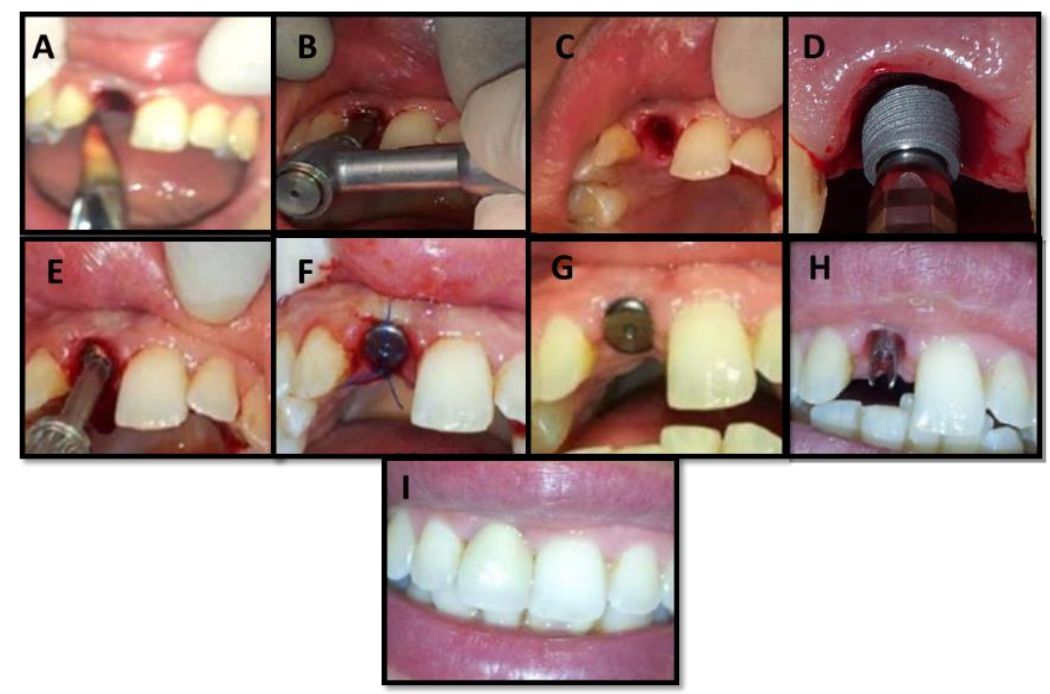

Fig. (5) : A) tooth 11 extraction with minimum trauma to the bone and in this technique (CII) the tooth removed completely and nothing remain in socket, B) implant site preparation, C) prepared extraction socket ready for implant insertion, D) \& E) insertion of the implant, F) insertion of the gingival former in the day of surgery, G) one week later suture removal, $\mathbf{H}$ ) abutment, I) Insertion of the crown after 10 days.

\section{Clinical Evaluation}

The implant was evaluated clinically for any mobility, presence of pain, infection, neuropathy, and radiographically to determine the implant success rate according to the Alberktsson's criteria (Albrektsson et al.; 1986). Also, the soft tissue was evaluated with the pink esthetic

Table (1): Distribution of Implanted Teeth. ${ }^{* S S T}=$ Socket Shield Technique, ${ }^{*} * \mathrm{CII}=$ Conventional Immediate Implant.

\begin{tabular}{ccccc}
\hline Treating Strategy & Centrals & Lateral & Canine & Total \\
\hline $\mathrm{SST}^{*}$ & 8 & 6 & 6 & 20 \\
\hline $\mathrm{Cll}^{* *}$ & 9 & 6 & 5 & 20 \\
\hline
\end{tabular}

Table (2): Torque of the Inserted Implant. *SST= Socket Shield Technique, ${ }^{* *} \mathrm{CII}=$ Conventional Immediate Implant.

\begin{tabular}{cccc}
\hline Treating Strategy & Insertion Torque & Immediate Loading & Delayed Loading \\
\hline SST $^{*}$ & $49 \mathrm{~N} \mathrm{~cm}$ & 19 & \\
\hline $\mathrm{ClI}^{*}$ & $51 \mathrm{~N} \mathrm{~cm}$ & 18 & 1 \\
\hline
\end{tabular}

\section{RESULTS}

Forty healthy adult patients within the inclusive criteria and age ranged between 28 years and 65 years for both males and females, with mean age of 51 years enrolled in this study. According to their sex, the males were 26 , and the females were 14. As shown in Figure (4). 


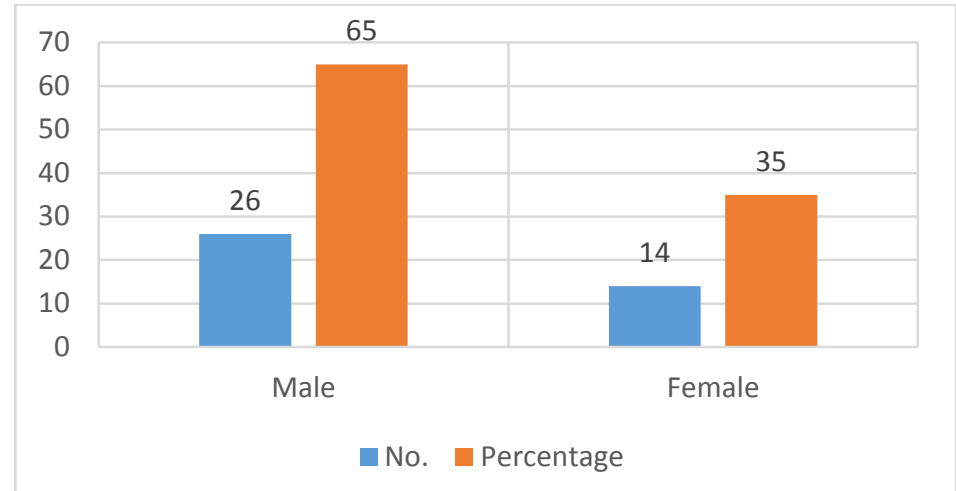

Fig. (6): A Diagram Showing the number and percentage of both male and female for this study.

Twenty patients were treated by socket shield technique and twenty patients treated by the conventional method of dental implantation. 19 out of the 20 of the patients treated by SST, survive till the time of finishing this study, and one case fails after two weeks of placement, which means a $95 \%$ survival rate. As shown in the

Figure

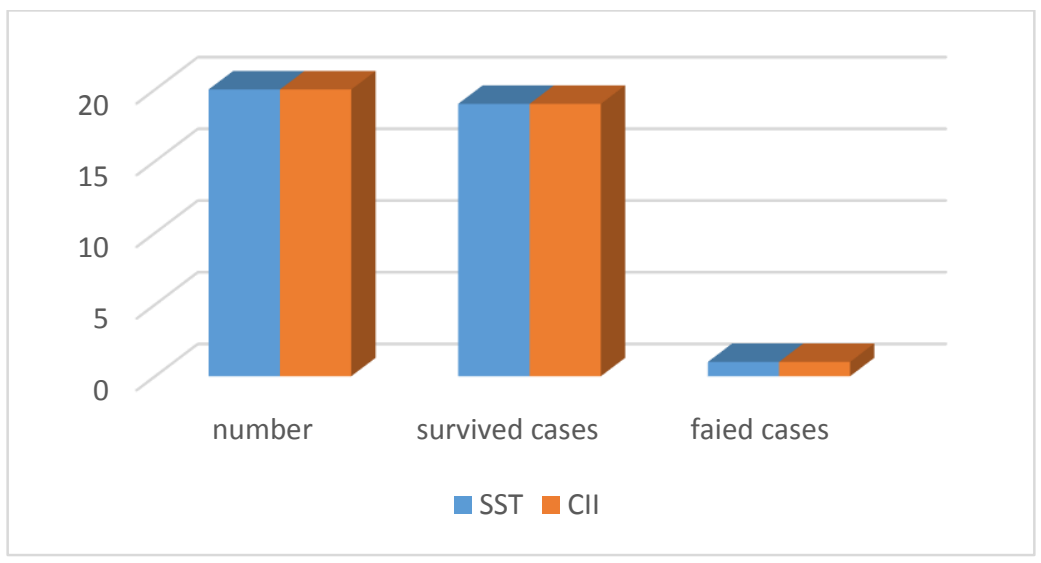

Fig. (7): A Diagram Showing the Success Rate for both socket shield technique (SST) and conventional Immediate Technique (CII) of Dental Implant.

Also, for the control group, the survival rate was $95 \%$. After one year, 5 cases needed soft tissue graft to manage gum recession and the inadequate band of keratinized tissue that affect the aesthetic appearance.

For the cases of SST that had got success, demonstrated excellent bone stability around the implant, no pathologies related to the root shield, no radiolucency around the shield, and no space was found between the implant and the root shield in most cases with good level of marginal bone. There were 2 cases one with internal and other external shield exposure, managed by reduction and then the soft tissue healed.

The pink esthetic score mean, of the SST on the day of starting was 12.5 and after finishing was 12.26 \pm 1.04 . While for control group the mean of PES was 12.6 at the beginning and 9.63 \pm 1.34 at the time of finishing of the study and that was obtained by two observers.

This study took about 12 months \pm two months and that difference of the PES between the SST and CII values was statistically significant with the $\mathrm{Z}$ test $(\mathrm{p}$-value $=0.001)$. As shown in 3. 
Table (3): Showing the Mean of Pink Esthetic Score for this Study. *Pink Esthetic Score. ** Standard deviation. $* * *$ High significant value.

\begin{tabular}{ccccc}
\hline Treating Strategy & PES* Day Zero & PES* After 1 Year & SD $^{\star *}$ & P-Value \\
\hline SST $^{*}$ & 12.5 & 12.26 & 1.04 & $0.001^{* * *}$ \\
\hline Cll** $^{* *}$ & 12.6 & 9.63 & 1.34 \\
\hline
\end{tabular}

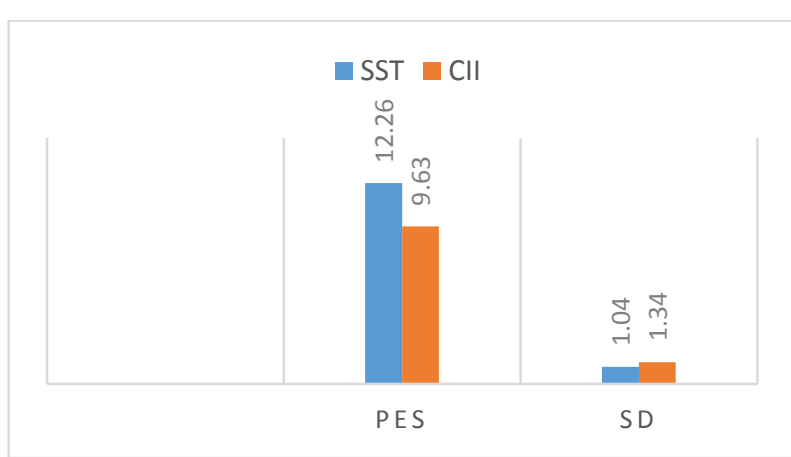

Fig. (8): The PES of both SST (blue color) and CII (red color) values after 1 year with the standard deviation of each

Also, some complications appeared in this study, and all were treated with special protocols of management. As shown in Table 4.

Table (4): Showing the number, type, and Management of Complications Appeared in this Study.

\begin{tabular}{cccc}
\hline Treating Strategy & No. & Type & Management \\
\hline SST $^{*}$ & 2 & External and Internal exposure of \\
the shield & $\begin{array}{c}\text { Reduction of the exposed fragment } \\
\text { with managing of soft tissue }\end{array}$ \\
\hline CII $^{* *}$ & 5 & $\begin{array}{c}\text { Inadequate keratinized tissue band } \\
\text { and gum recession }\end{array}$ & $\begin{array}{c}\text { Soft tissue grafts done about 1 year } \\
\text { later }\end{array}$ \\
\hline
\end{tabular}

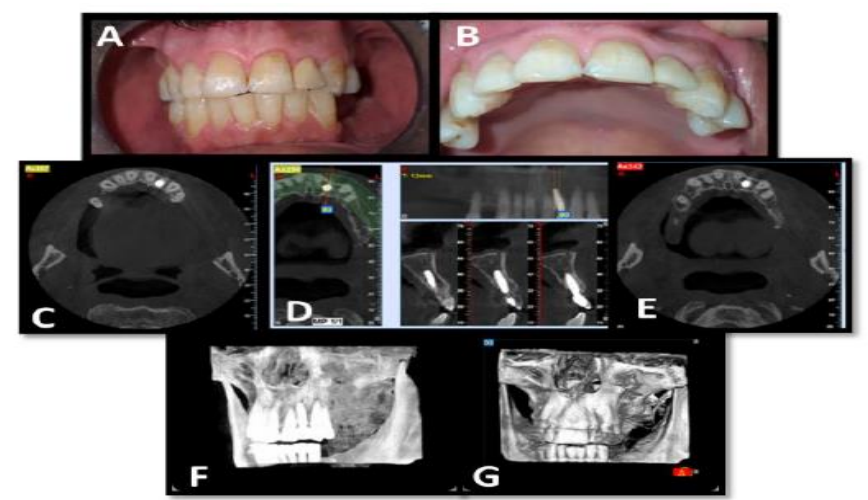

Fig. (9): Showing the clinical and radiographical evaluation of SST study case of the tooth no. 22 showing the successof that case done 11 months after implant placement; A and B: photographs showing the condition of the soft tissue. C, D, E, F and G multi views of CBCT images evaluating the implant and showing the success. 


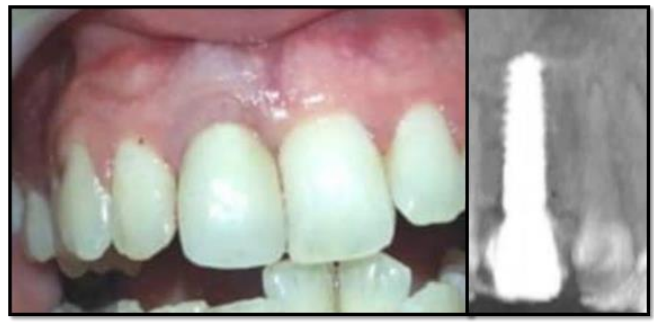

Fig. (10): clinical and radiographical image for the tooth 11 with CII after 1 year.

\section{DISCUSSION}

The immediate implant and SST of this study had high success rates as well as delayed technique.in this study the survival rate for both technique was $95 \%$, this result is compatible to Gluckman et al, study with survival rate $96.1 \%$ (12).

In addition to the success rate, there was benefit of less time consumed, but still there was unpredictable esthetic outcome with the conventional immediate implant group while it was predictable with SST group, which result in more satisfaction for the implant team and the patients.

The PES for the SST in this study was 12.05 , and this is compatible with the result of the study that was done by Bramanti et al, and Bäumer et al. $(13,14)$.

Another point to be mentioned about the result is that when we followed up the cases, none of the SST cases were indicated for soft tissue graft, while in study cases of conventional immediate implantation some cases have soft tissue loss, which suggests the need for soft tissue management.

There is additional benefit of the socket shield technique which acts as a guide for implant placement in Bucco-palatal and mesio_distal direction, as Implant placement must be done with correct three -dimensional positioning which prevents unfavorable poor esthetic and biological results, for more explanation; a more buccal position implant may cause a high risk of recession of marginal mucosa, on the other hand, an implant being placed more palatally can cause restoration overhang or an inferior emergence profile, while placement of implant in an inappropriate mesio_distal position can affect the form and size of papilla negatively, finally malpositioning of implant in corono-apical direction can cause biological complications if placed too deeply or esthetic complication if the metal of the implant is visible (15). In addition to the correct position of implant placement, the amount of bone that is available in the planned site for insertion of the dental implant and the relation of that bone to the soft tissue play essential role in the esthetic outcome (16). 0The health and stability of soft tissue around the dental implants are essential for its success and long term maintenance, a wide band of two millimeters of keratinized tissue favorable to provide a soft tissue seal around natural teeth (17).

The soft tissue surrounding implants with SST was highly acceptable esthetically which can be explained by the fact mentioned before, that this technique preserves the periodontium and keep the same blood supply of natural teeth, i.e. the blood supply to the buccal bone that is from 2 sources in SST, while it is from one source in conventional immediate implant. As it is known that gingival biotype and thickness of bone is very important for the success of dental implant, so at the end if this study the result of the socket shield technique was satisfying with the presence of enough bone and gingiva that increased the esthetic outcome.

\section{CONCLUSION}

With the limitation of this study it was concluded that SST is a good modality of treatment when it is possible according to the criteria mentioned before and to be done with well experienced and skilled clinician and team, and this technique is favorable especially in the esthetic zone with advantages of decrease the total treatment time needed, more preservation of bone and the contour of soft tissue around dental implant that lead to the optimal esthetic 
result, so that the soft tissue related to the placed dental implant get closure to natural tooth appearance, which make this technique the superior in that point, in addition to that mostly there will be no need for other correcting and repairing procedures like ridge preservation, augmentation or soft tissue grafts that increase the visits and cost of the implant restoration, and with a high success rate as the other techniques in addition presence of root shield technique act as a guide for correct placement of dental implant in Bucco-palatal and mesio_distal direction.

\section{REFERENCES}

Ortega-Martínez, J., Pérez-Pascual, T., MarequeBueno, S., Hernández-Alfaro, F., FerrésPadró, E., 2012. Immediate implants following tooth extraction. A systematic review. Medicina Oral, Patología Oral y Cirugía Bucal 17, e251. doi.org/10.4317/medoral.17469.

Miltiadis E. Mitsias, Konstantinos D. Siormpas, Georgios A. Kotsakis, Scott D. Ganz, Carlo Mangano, and Giovanna Iezzi, "The Root Membrane Technique: Human Histologic Evidence after Five Years of Function," BioMed Research International, vol. 2017, Article ID 7269467, 8 pages, 2017. https://doi.org/10.1155/2017/7269467.

Esteve-Pardo, G., Esteve-Colomina, L., 2018. Clinical Application of the Socket-Shield Concept in Multiple Anterior Teeth. Case Reports in Dentistry 2018, 1-7. https://doi.org/10.1155/2018/9014372.

Craddock, H.L., 2009. Consequences of Tooth Loss: 1. The Patient Perspective - Aesthetic and Functional Implications. Dental Update 36, 616-619.

https://doi.org/10.12968/denu.2009.36.10.616.

Nevins M, Camelo M, De Paoli S, et al. A study of the fate of the buccal wall of extraction sockets of teeth with prominent roots. Int $\mathrm{J}$ Periodontics Restorative Dent 2006; 26:19-29.
Viña-Almunia, J., Candel-Martí, M.E., CerveraBallester, J., García-Mira, B., Calvo-Guirado, J.L., Peñarrocha-Oltra, D., Peñarrocha-Diago, M., 2013. Buccal bone crest dynamics after immediate implant placement and ridge preservation techniques: review of morphometric studies in animals. Implant Dent 22, 155-160. http:// doi.org/10.1097/ID.0b013e318287a947.

Choi, Sunyoung, In-Sung Yeo, Sung-Hun Kim, JaiBong Lee, Chan Wook Cheong, and Jung-Suk Han. 2015. “A Root Submergence Technique for Pontic Site Development in Fixed Dental Prostheses in the Maxillary Anterior Esthetic Zone." Journal of Periodontal \& Implant Science $\quad 45 \quad$ (4): $152-55$. https://doi.org/10.5051/jpis.2015.45.4.152.

Vanhoutte, V., Rompen, E., Lecloux, G., Rues, S., Schmitter, M., Lambert, F., 2014. A methodological approach to assessing alveolar ridge preservation procedures in humans: soft tissue profile. Clin Oral Implants Res 25, 304309. https://doi.org/10.1111/clr.12144.

Hürzeler, M.B., Zuhr, O., Schupbach, P., Rebele, S.F., Emmanouilidis, N., Fickl, S., 2010. The socket-shield technique: a proof-of-principle report. J. Clin. Periodontol. 37, 855-862. https://doi.org/10.1111/j.1600051X.2010.01595

Kumar, Payal Rajender, and Udatta Kher. 2018. "Shield the Socket: Procedure, Case Report and Classification." Journal of Indian Society of Periodontology $22 \quad$ (3): 26672.doi.org/10.4103/jisp.jisp_78_18.

Gharpure, A.S., Bhatavadekar, N.B., 2017. Current Evidence on the Socket-Shield Technique: A Systematic Review. Journal of Oral Implantology. doi.org/10.1563/aaid-joi-D-1700118. 
Gluckman H, Salama M, Du Toit J. A retrospective evaluation of 128 socket-shield cases in the esthetic zone and posterior sites: Partial extraction therapy with up to 4 years followup. Clin Implant Dent Relat Res. 2017; 00:18. https://doi.org/10.1111/cid.12554.

Bramanti, E., Norcia, A., Cicciù, M., Matacena, G., Cervino, G., Troiano, G., Zhurakivska, K., Laino, L., 2018. Postextraction Dental Implant in the Aesthetic Zone, Socket Shield Technique Versus Conventional Protocol. J Craniofac Surg 29, 1037-1041.

Bäumer D, Zuhr O, Rebele S, Hürzeler M. Socket Shield Technique for immediate implant placement - clinical, radiographic and volumetric data after 5 years. Clin. Oral Impl. Res. 28, 2017, 1450-1458 doi: 10.1111/clr.13012.

Darby, I., Chen, S.T., Buser, D., 2009. Ridge preservation techniques for implant therapy. Int J Oral Maxillofac Implants 24 Suppl, 260271.

Mezzomo, L.A., Shinkai, R.S., Mardas, N., Donos, N., 2011. Alveolar ridge preservation after dental extraction and before implant placement: a literature review. Revista Odonto Ciência 26 , 77-83. https://doi.org/10.1590/S198065232011000100017.

Cho, S.-C., Froum, S.J., Kamer, A.R., Loomer, P.M., Romanos, G., Demiralp, B., 2015. Implants in the Anterior Maxilla: Aesthetic Challenges. International journal of dentistry 2015, 152420. doi.org/10.1155/2015/152420. 


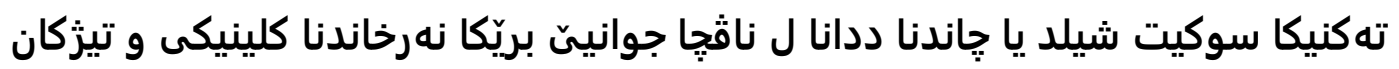
بوخته

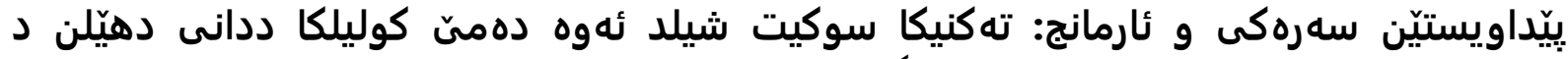

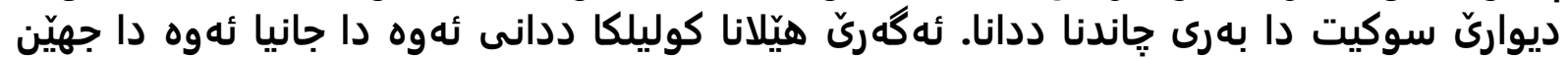

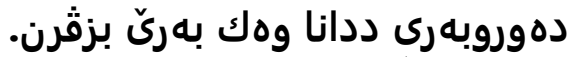

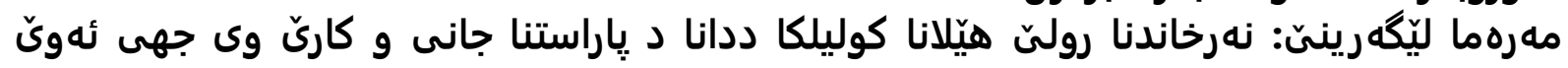

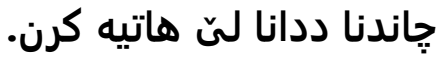

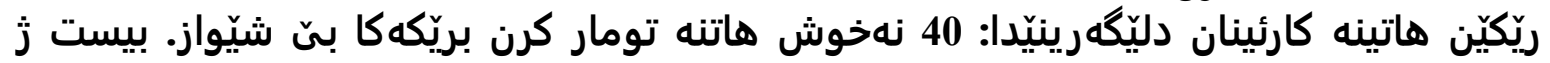

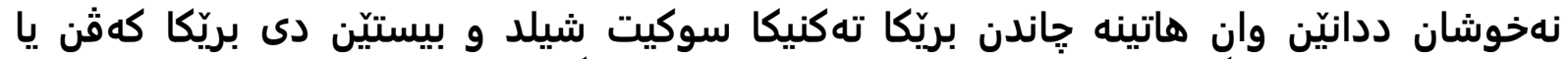

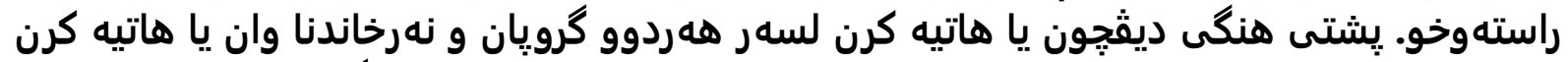

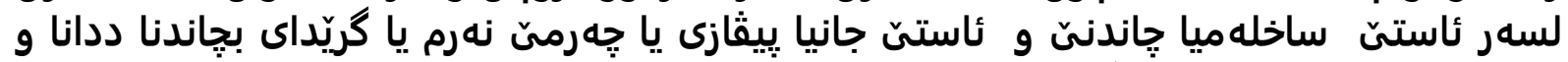

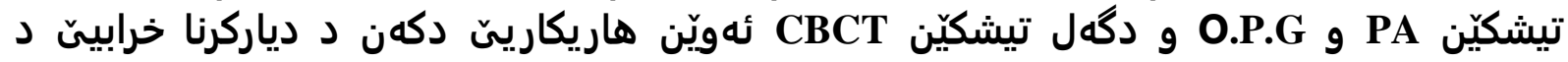

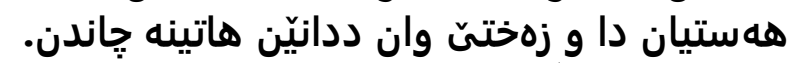

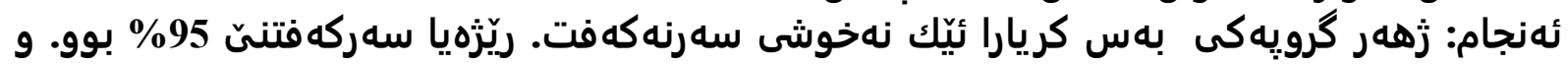

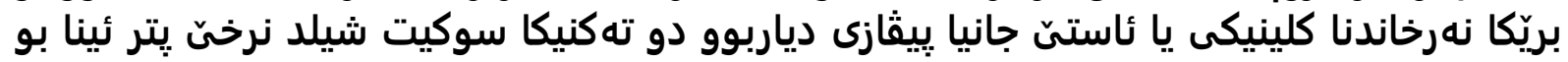

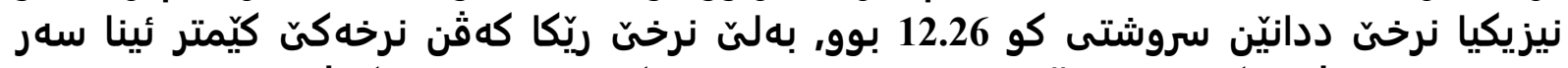

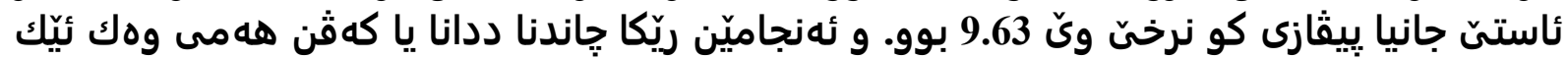

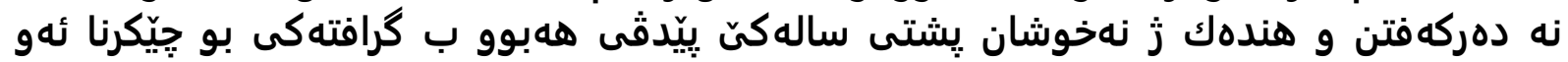

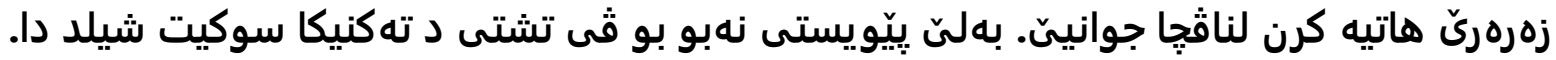

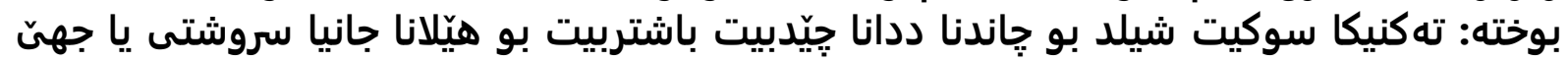

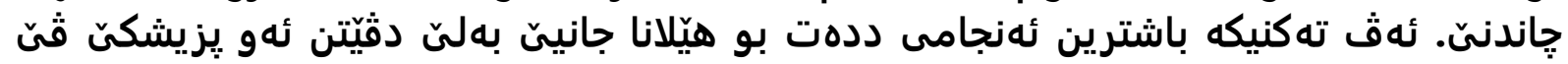

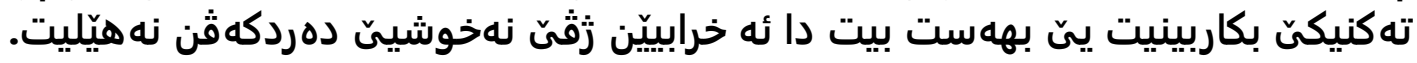

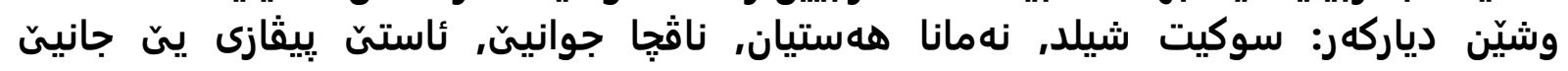


تقنية سوكت شيلد (Socket Shield) لزراعة الاسنان في المنطقة الجمالية, تقييم سريري وبواسطة صور الاشعه لاسن الطقة

الخلاصه

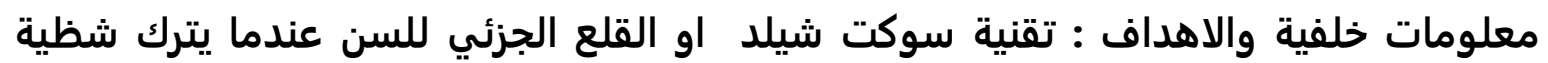

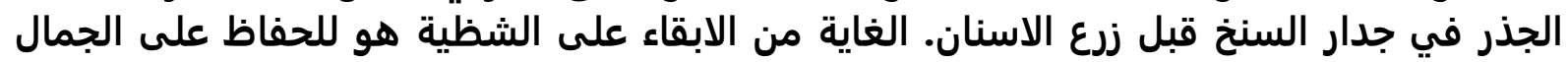

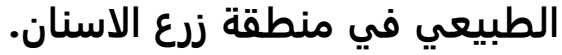
الغاية من الدراسة : لتقييم دور الابقيقاء على الشئية الشية الجذرية في الحفاظ على جمالية وفعالية المنطقة التي اجرى العملية عليها.

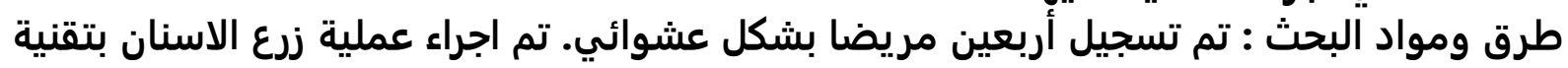

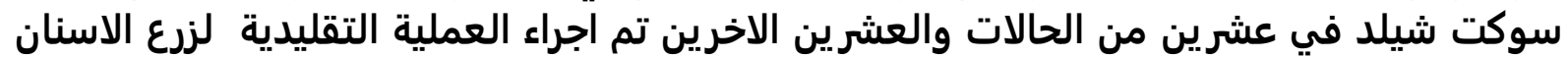

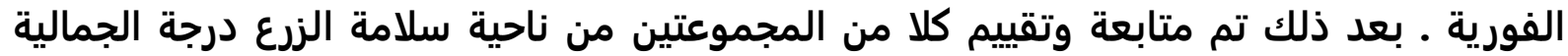

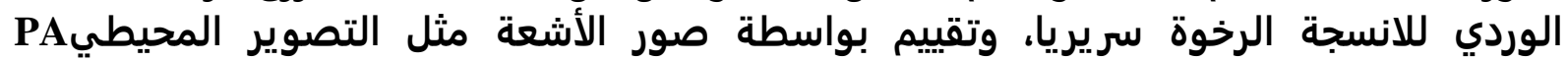

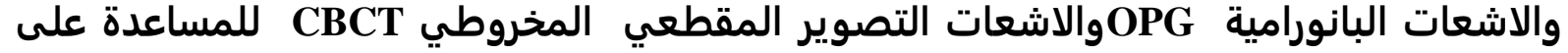

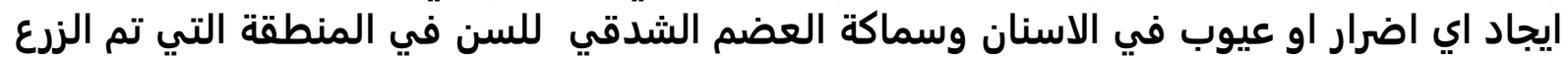

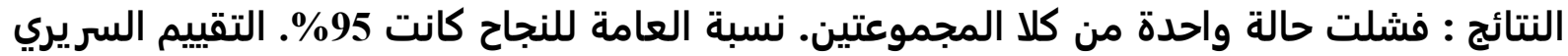

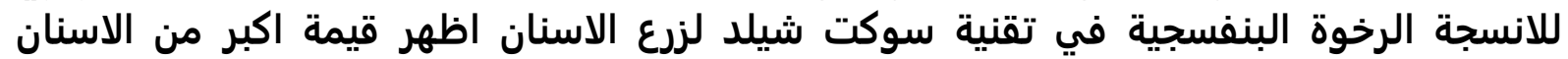

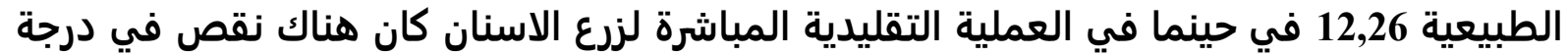

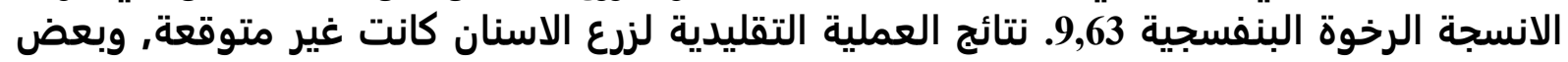

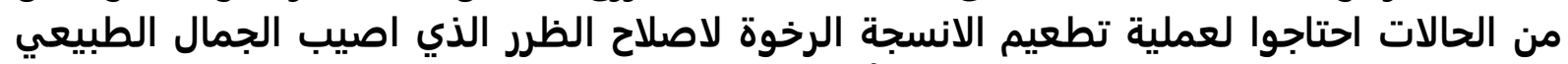

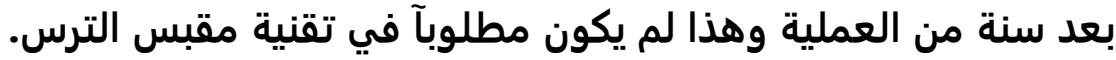

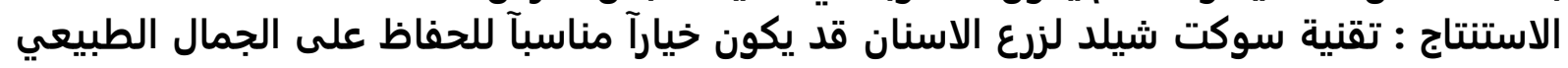

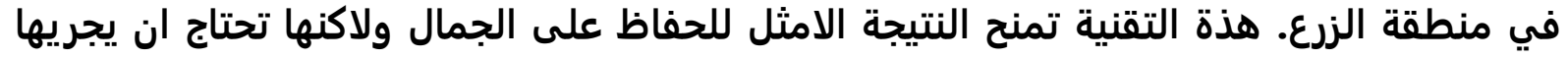

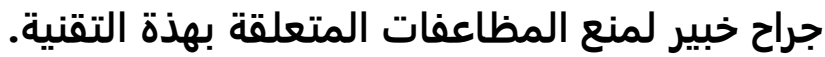
الكلمات الدالة :سوكت شيلد, فقدان العظام, المنطقة الجمالية, درجة الجمالية الوردي. 